\title{
Dynamics of nanostructure surfaces and ways to approach them
}

Hansen, Thomas Willum; Liu, Pei; Lomholdt, William B.; Larsen, Matthew Helmi; Núñez Valencia, Cuauhtémoc; Schiøtz, Jakob

Link to article, DOI:

$10.22443 /$ rms.mmc2021.129

Publication date:

2021

Document Version

Publisher's PDF, also known as Version of record

Link back to DTU Orbit

Citation (APA):

Hansen, T. W., Liu, P., Lomholdt, W. B., Larsen, M. H., Núñez Valencia, C., \& Schiøtz, J. (2021). Dynamics of nanostructure surfaces and ways to approach them. Abstract from Microscience Microscopy Congress 2021. https://doi.org/10.22443/rms.mmc2021.129

\section{General rights}

Copyright and moral rights for the publications made accessible in the public portal are retained by the authors and/or other copyright owners and it is a condition of accessing publications that users recognise and abide by the legal requirements associated with these rights.

- Users may download and print one copy of any publication from the public portal for the purpose of private study or research.

- You may not further distribute the material or use it for any profit-making activity or commercial gain

- You may freely distribute the URL identifying the publication in the public portal

If you believe that this document breaches copyright please contact us providing details, and we will remove access to the work immediately and investigate your claim 


\section{Dynamics of nanostructure surfaces and ways to approach them}

Thomas W. Hansen ${ }^{1}$, Pei Liu ${ }^{1}$, William B. Lomholdt ${ }^{1}$, Matthew Helmi Leth Larsen ${ }^{2}$, Cuauhtémoc Núñez Valencia ${ }^{2}$ and Jakob Schiøtz ${ }^{2}$

${ }^{1}$ DTU Nanolab, Technical University of Denmark, DK-2800 Kgs. Lyngby, Denmark

${ }^{2}$ DTU Physics, Technical University of Denmark, DK-2800 Kgs. Lyngby, Denmark

In situ electron microscopy is a unique method for imaging materials in their operating state, monitoring growth phenomena at the atomic scale and observing the dynamic changes of particularly surfaces [1]. Data collected under operating conditions tells a lot more about the performance and stability of a material than that acquired under high vacuum conditions. In situ electron microscopy investigations have been performed through modification to the microscope column by inserting pressure-limiting apertures. Over the last decade, the use of electron transparent membranes has been more mainstream. Whereas the former requires microscope modifications, it sets no restrictions on the sample holders. The latter makes use of a dedicated holder that can be moved between different microscope installations. However, the electron beam can have a significant influence on the structure of materials, particularly under non-vacuum conditions.

With recent development of camera technology, the use of in situ imaging has become even more interesting. The latest generation of cameras provide high sensitivity and high frame rates making it possible to detect dynamic phenomena such as particle migration and mobility of atomic columns with a higher temporal resolution than previously while keeping the electron dose rate at a minimum. Even at low electron dose rates, we can detect individual atomic columns and track them in time.

The recent developments facilitate the analysis of nanoscale dynamics of materials. Particularly in catalysis, the surface structure and how the surface configuration changes with changing surroundings have attracted tremendous attention and has been the topic of several investigations using a plethora of experimental approaches $[2,3]$. We have studied mainly the surfaces of gold nanoparticles supported on cerium dioxide under condition relevant for $\mathrm{CO}$ oxidation.

Using environmental transmission electron microscopy, gold nanoparticles were subjected to hydrogen, oxygen and carbon monoxide containing atmospheres at elevated temperatures. Several types of structural changes were observed and an attempt at categorizing these events was made [4]. In presence of a hydrogen gas a concerted motion of surface atoms was observed. Entire layers at the $\{100\}$ facet moves in a concerted fashion to a different location on the nanoparticle and reappears later, as seen on Figure 1 . The process is observed continuously during image recording. As the temperature is increased, the process occurs faster. Under similar conditions, the topmost layer of the $\{111\}$ facet was observed to glide parallel to the surface, still in a concerted fashion, as seen on Figure 2.

In this work, we will show our observation of different changes observed in gold nanoparticle samples and our attempt at understanding the underlying dynamic processes and the effect of the electron beam. We will show recent results and discuss the progress of our work and future possibilities. 
[1] T. W. Hansen, J. B. Wagner, Eds., Controlled Atmosphere Transmission Electron Microscopy, (Springer, 2016), pp. 329.

[2] H. Yoshida, Y. Kuwauchi, J. R. Jinschek et al., Science 335, (2012) 317-319.

[3] P. Liu, T. T. Wu, J. Madsen et al., Nanoscale 11, (2019) 11885-11891.

[4] P. Liu, J. Madsen, J. Schiøtz et al., J. Phys.: Mater. 3, (2020) 024009. 